\title{
ARBITRARINESS OF SOUND SYMBOLYSM IN ENGLISH AND JAPANESE
}

\author{
Dariia Rzhevska ${ }^{1}$
}

\begin{abstract}
The article determines that the form of a word bears an arbitrary relation to its meaning accounts only partly for the attested relations between form and meaning in the world's languages. A long history of research has considered the role of iconicity in language and the existence and role of non-arbitrary properties in language and the use of language. Recent research in English and Japanese suggests a more textured view of vocabulary structure, in which arbitrariness is complemented by iconicity (aspects of form resemble aspects of meaning) and systematicity (statistical regularities in forms predict function). Sound symbolism is the systematic and non-arbitrary link between word and meaning. Although a number of behavioral studies demonstrate that both children and adults are universally sensitive to sound symbolism in mimetic words, the neural mechanisms underlying this phenomenon have not yet been extensively investigated. Experimental evidence suggests these form to meaning correspondences serve different functions in language processing, development and communication: systematicity facilities category learning by means of phonological cues, iconicity facilitates word learning and communication by means of perceptuomotor analogies, and arbitrariness facilitates meaning individuation through distinctive forms. For one, there can be external reasons why a particular form would go with a given meaning, such as sound symbolism. Also, there are systematicities in English, as well as, in Japanese, where words with similar forms are more likely than chance to have similar meanings. The article also relates to a comparative methods used to test what it is that leads phonæsthemes to be mentally represented, measuring effects of frequency, cue validity, and sound symbolism.
\end{abstract}

\section{Keywords}

Sound symbolism, mimetics, onomatopoeia, arbitrariness, idiophones, iconicity.

1. Introduction. The longstanding view that the form of a word has an essentially arbitrary relation to the word's meaning is giving way to a perspective that recognises roles for both arbitrariness and non-arbitrariness in language. Recent research from across the cognitive sciences is revealing substantial patterns of no arbitrariness in the vocabulary and investigating mechanisms for how it comes about. This review traces two recent developments that are key in enabling a paradigm change: our access to linguistic facts has changed, revealing that forms of non-arbitrariness are more widespread than previously assumed; and our understanding of the mechanisms underlying the distribution of arbitrary and non-arbitrary aspects of language structure is rapidly advancing, spurred on by innovations in methods and theory. These developments are already making an impact in the study of language and mind. As understanding advances, idealised conceptions give way to more refined models of language form and language function, and recent theoretical insights have led to distinctions in the ways in which words are nonarbitrary. Studies on non-arbitrariness in terms of morphological structure, syntactic and discourse structure have highlighted numerous correspondences between meaning and linguistic form.

It is generally acknowledged by linguists that when a word is correlated with an object in the real world,

\footnotetext{
1 Lecturer Dariia O. Rzhevska, Academic and Research Institute of International Relations, National Aviation University, prosp. Kosmonavta Komarova 1, Kyiv,03058, Ukraine; tel.: +380967361698; e-mail: by_odry@ua.fm
}

the word is called "sound symbolism". This correlation can be formalized by onomatopoeia or mimetic words. Symbolic words are generally accepted as a phenomenon of language. Some feel that language is mainly arbitrary and that sound symbolism is a mere fringe phenomenon; others aver that language is inherently sound symbolic and always striving to equate sound with sense.

2. Methodology. Many natural languages manifest sound-symbolic phenomena through depictive words of sensory imagery where the speaker's sensory experiences resemble the linguistic signs that denote them (Dingemanse, 2012a; Nuckolls, 1999; Perniss et al., 2010). Although such sound-symbolic words are rare and underdeveloped in Indo-European languages, they are widely attested in human language in general (Diffloth, 1972; Voeltz \& Kilian-Hatz, 2001). In the course of research, various terms have been introduced to refer to them in different languages. They include 'expressives' (Diffloth, 1972; Klamer, 2001; Tufvesson, 2011) in South-East Asian languages, 'ideophones' (Childs, 1994; Dingemanse, 2011; Doke, 1935; Nuckolls, 1996) mostly in sub-Saharan African languages and indigenous languages of South America, 'mimetics' (Akita, 2009; Hamano, 1998; Kita, 1997; Mester \& Itô, 1989) in Japanese, and phonaesthemic words that contain 'phonaesthemes' (Abelin, 1999; Bergen, 2004; Firth, 1930; Hutchins, 1998) in Indo-European languages. In order to avoid terminological issues detrimentally affecting the cross-linguistic study, Dingemanse (2012b) employs 'ideophones' as a common reference point which serves as a facilitator "for discussion of language-particular solutions to the generic 
problem of depicting sensory imagery in words". In detail, Dingemanse (2011, p. defines the term 'ideophone' as "marked words that depict sensory imagery" and posits that this definition is designed to cover semantic-functional and structural similarities found in the phenomenon across languages. Dingemanse's definition of ideophones captures cross-linguistically recurrent properties of sound symbolic words, namely, "their structural markedness, their syntactic aloofness, or their imagistic semantics"2. Such a cross-linguistic term is beneficial to avoid possible vagueness in the use of the notions in the linguistic literature and to cross-linguistically investigate the sound-symbolic phenomenon. Notwithstanding the benefits that the cross-linguistic term can bring, it is still important to understand language-internal terms, since they provide a basis for justifying the to be claimed to have cross-linguistically recurrent properties of sound-symbolic words and they also enable us to apply method of observation and descriptive one to the specific details of the generally recurrent properties of sound-symbolic words in particular languages.

As an object of this study the phenomenon of sound symbolism both in English and Japanese is a highly controversial topic in numerous language studies. An antithesis to sound symbolism, which does exhibit an apparent connection between sound and sense, arbitrariness is one of the characteristics shared between all languages. In linguistics arbitrariness is the absence of any natural or necessary connection between a word's meaning and its sound or form. So, arbitrariness is the subject of this study to show either sound symbolic word can be considered to arbitrary. Every language can be assumed to be arbitrary, at least in this linguistic definition of the word, despite occasional iconic characteristics. Instead of universal rules and uniformity, then, language relies on associations of word meanings deriving from cultural conventions. Descriptively, the existence of such "systematic preferences for certain sound-meaning mappings" may be termed 'sound symbolism', if we use 'sound symbolism' in its broad sense ${ }^{3}$. Explanatorily, the question is whether such correlations are primarily based on language-internal arbitrary conventions ${ }^{4}$, or

\footnotetext{
${ }^{2}$ Abelin, Å. (1999). Studies in sound symbolism. Ph.D. dissertation, Göteborg University. (2012). Relative frequency and semantic relations as organizing principles for the psychological reality of phonaesthemes. Selected Articles from UK-CLS Meetings, 1, pp.128- 145.

3 Monaghan, P., Mattock, K., \& Walker, P. (2012). The role of sound symbolism in language learning. Journal of Experimental Psychology: Learning, Memory, and Cognition, 38(5), pp. 1152-1164.

${ }^{4}$ Firth, J. (1930), Speech. London: Ernest Benn, London: Oxford University Press, 1964.

5 Hockett, C. F. (1960). The origin of speech. Scientific American, 203, 89-96.
}

on natural motivation. The latter hypothesis is 'sound symbolism' in the narrow sense, and for the purposes of this thesis will be formulated as the Explanatory Sound-symbolism Hypothesis (ESH). It states that despite the received view that language is fundamentally governed by arbitrariness ${ }^{5}$, many languages contain linguistic signs where natural motivation prevails over arbitrariness in their sound-symbolic vocabularies. The alternative hypothesis to the ESH is the Conventional Sound-symbolism Hypothesis (CSH): arbitrary convention prevails over natural motivation in sound-symbolic vocabularies. The ESH does not posit that natural motivation alone determines sound-symbolic phenomena. In fact, there are no totally non-arbitrary signs in spoken language. Thus, while admitting the role of arbitrariness in the sound-symbolic words, the present thesis aims to investigate any possible pervasiveness of natural motivation in cross-linguistic instances of sound symbolism and provide empirical evidence for assessing the validity of the ESH. The languages chosen here for gathering sound-symbolic words are Japanese and English, which are historically and linguistically unrelated.

In studying language, it is often pointed out that the connection between any word and what it signifies is arbitrary; that is, there is no a priori, compelling reason why, for instance, the domesticated four-legged canine animal should be called dog, though it could very well have been pig. It was coincidental that this animal was named dog and it was through centuries of conventional use that dog became the linguistic sign in English to refer to this actual animal. The principle behind the arbitrariness of meaning-symbol connection holds up across languages. Nevertheless, there is a class of words in languages where the sound-meaning relationship shows certain connections. Such is the case with onomatopoeia, which is defined in the American Heritage Dictionary as words that "imitate the sounds associated with the objects or actions they refer to", such as "buzz" or "murmur".

A similar question about whether the English language is growing more or less sound-symbolic or whether it maintains a 'steady state' equally remains unanswerable. Sound symbolism has been found in many languages. High front vowels in English represent soft or small sounds (ping, click), whereas low and back vowels represent larger, louder sounds (bang, boom). Even if there are exceptions to every pattern in human languages, it can be demonstrated that some sound symbolism has a biological basis.

Sound symbolism is often the result of a secondary association. The words glow, gleam, glimmer, glare, glisten, glitter, glacier, and glide suggest that in English the combination $g l$ - conveys the idea of sheen and smoothness. Against this background, glory, glee and glib emanate brightness by their very form, glance and glimpse reinforce our conclusion (because eyesight is inseparable from light), and glib has no other choice than to denote 
specious luster, and, indeed, in the sixteenth century, when it became known in English, it meant 'smooth and slippery.

Compatible with this view, iconicity is not exclusive to signed languages. Despite the dominance of arbitrary form-meaning relations, all spoken languages have a repertoire of words for which the relationship between form and meaning is not arbitrary. Consider the English onomatopoetic words moo, bow-wow, and ding-dong in which the sounds of the words iconically represent the meaning.

All the words having a rhyme

-ump, refer to a rounded, or at least non-pointy, protuberance. For example, the word bump means a contact involving something weighty whether it is hips, bottoms, or shoulders, or a slow-moving vehicle or vessel, but not the contact of a point with a surface, such as a pencil tapping a window pane. The word crump of an exploding shell fits in here, as does thump. You might also consider rumble, and possibly mumble and tumble, though admittedly this is -umble rather than -ump. One has to allow that there can be words with -ump that do not fit the correlation. Trump is an example. However, there are enough examples to suggest there is a connection between sound and meaning in one set of words ${ }^{6}$.

There are different examples of symbolic words in English which can be:

a. related to use of a voice or intonation to express speaker's emotional or physical status. It includes unconscious symptomatic voices like cough or hiccup.

i) Aaugh!

ii) Achoo!

b. Sound-imitating Symbolic words - Related to onomatopoeia expressing environmental sounds. It includes crying sounds of birds or animals.

i) Onomatopoeia: crow, hiccup, meow, plop

ii) Reduplicative onomatopoeia: chitter-chatter, moo-moo, puff-puff

c. Synesthetic Symbolic words - defined as an acoustic symbolism of non-acoustic phenomenon. These symbolic words show that phonetically natural words are systematically related to the expression of size.

i) small (or soft) sound: high front vowel, voiceless consonant, high tone - ping, click

ii) large (or louder) sound: low back vowel, voiced consonant, low tone - bang, boom

\footnotetext{
${ }^{6}$ Itô, J., \& Mester, A. (1996). Japanese Phonology. In J. Goldsmith (Ed.), The Handbook of Phonological Theory (pp. 817-838). Massachusetts: Blackwell Publishers. (1999). The Phonological Lexicon. In N. Tsujimura (Ed.), The Handbook of Japanese Linguistics (pp. 62-100). Malden, MA/Oxford: Blackwell Publishers.

7 Kakehi, Hisao; Tamori, Ikuhiro; Schourup, Lawrence Clifford. (1996). Dictionary of iconic expressions in Japanese, Berlin: Mouton de Gruyter.
}

While English has a fairly limited set of onomatopoetic words, some spoken languages such as Japanese and Korean have a much larger inventory (several thousand entries, including both common and very rare examples, are found in one Japanese dictionary of iconic expressions ${ }^{7}$. These words cover not only onomatopoeia but also sound-symbolism related to other sensory experiences, manner, and mental-emotional states.

According to one conservative estimate, Japanese makes use of onomatopoeia three times as often as English. In Japanese, onomatopoeia is used in all kinds of prose and speech, formal or informal, whenever a precise, apt description is demanded.

There are two phenomena surrounding the use of onomatopoeia. First is the question as to what the speakers of Japanese implicitly understand the tacit rules needed to interpret or generate new onomatopoeia. The wide applicability of these rules means that brand new onomatopoeic words made up by someone are be readily understood as conveying a certain sense. The second concerns what sort of activities Japanese onomatopoeia covers. For although true onomatopoeia usually refers to words imitating sounds occurring in nature, many onomatopoeic words in Japanese are capable of describing activities and states that do not involve sound.

3. Results and discussion. By evaluating the range of classifying the examples of symbolic words, we are one step closer to understanding that symbolic words have universality. Since the purpose of language is communication, the criterion for evaluation of the universality of symbolic words is whether one easily-understands naturally or not. In other words, the understanding of symbolic words needs to be natural in order to have universality. If the symbolic words are not easily-understood, then they can be considered to be arbitrary. As shown above, English symbolic words are classified by physical, sound-imitating, synesthetic and conventional ways while Japanese symbolic words are classified in six ways: visual, auditive, tactile, taste, smell and mental. Thus, English and Japanese seem to have a different categorization of symbolic words, respectively four ways to six. These ways are actually similar because Japanese just have more concrete in expressions. However, if there is a clear difference, it is that English is closer to an academic use of the language while Japanese is closer to a pragmatic view of it, in which the language user's feeling is highlighted. Therefore, how natural symbolic words are in the academic and pragmatic views of language is the criteria for evaluating universality.

In pragmatic view, the remaining ways, namely the: physical, sound-imitating, visual, auditive, tactile, taste, smell and mental are reviewed. For example, in English the cat cries 'meow' while in Japanese the cat cries 'nya'. The words 'meow' 'nya' start with the 
Sound symbolism types in different languages

Table 1

\begin{tabular}{|c|c|c|c|c|c|c|c|}
\hline & mouse & cat & $\begin{array}{l}\text { goat// } \\
\text { sheep }\end{array}$ & dog & pig & horse & cow \\
\hline Korean & $\mathrm{t}[\mathrm{ikt}$ ik & $\begin{array}{l}\text { jaon } \\
\text { njaorn }\end{array}$ & $\begin{array}{l}\text { mææ: } \\
\text { mæhæ: }\end{array}$ & 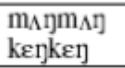 & kulkul & hihi:hin] & tm: \\
\hline Japanese & t jiju: & $\begin{array}{l}\text { nija: } \\
\text { nijan }\end{array}$ & me:me: & wanwan & bu:bu: & hihin & mo: \\
\hline Chinese & $\left.\left.\mathrm{t} \int \mathrm{it}\right] \mathrm{it}\right] \mathrm{i}$ & $\begin{array}{l}\text { mimio } \\
\text { mijao }\end{array}$ & $\begin{array}{l}\text { mimi: } \\
\text { mimie: }\end{array}$ & WaWaWa & ththth & ahahaha & пa: \\
\hline Finnish & руррур & miau & mæ:æ: & $\begin{array}{l}\text { hauhau } \\
\text { vuhvuh }\end{array}$ & røhrøh & ihaha: & am:u: \\
\hline Estonian & pi:p & miau & $\begin{array}{l}\text { møk: } \\
\text { mæ: }\end{array}$ & auxaux & øhøh & ihaha & mu: \\
\hline Urdu & $\left.t \int i t\right] i$ & miaow & $\begin{array}{l}\text { me: } \\
\text { be: }\end{array}$ & bonbon & - & - & $\mathrm{m}:$ \\
\hline Persian & - & miau & be:be: & howhow & korokoro & $\begin{array}{l}\text { hihihi: } \\
\text { dantJo }\end{array}$ & me: \\
\hline Kurdish & бikoikðik & miau & $\begin{array}{l}\text { be: } \\
\text { me: }\end{array}$ & WowWวW & - & - & $\begin{array}{l}\text { ma: } \\
\text { borabor }\end{array}$ \\
\hline Arabic & - & miau & $\begin{array}{l}\text { me: } \\
\text { ba: }\end{array}$ & habhab & - & heehee & bu: \\
\hline Polish & pipi & miau & me: & hauhau & - & hihi & mu: \\
\hline English & $\begin{array}{l}\text { skwi:k } \\
\text { i:k }\end{array}$ & miau & ba: & $\begin{array}{l}\text { bauwau } \\
\text { wofwof } \\
\text { japjap }\end{array}$ & oink.oink & neigh & mu: \\
\hline Swedish & pi:p pi:p & miau & $\begin{array}{l}\text { bæ: } \\
\text { mæ: }\end{array}$ & $\begin{array}{l}\text { vuv:uv } \\
\text { vufvuf }\end{array}$ & nøf:nøf: & gneg:neg & mu \\
\hline Spanish & - & miau & be:be. & guau & oinkoink & - & mu: \\
\hline Icelandic & pi:p pi:p & miau & mæ: & vufvuf & & njihaha & $\mathrm{m} \ddot{\mathbf{e}}$ \\
\hline Hungarian & - & miau & $\begin{array}{l}\text { bæ:ææ } \\
\text { mækmæk }\end{array}$ & vauvau & røf:røf: & - & mu: \\
\hline
\end{tabular}

same phonetic properties of [+nasal] as below illustrates, yet they have different writings and are pronounced differently. In other words, some symbolic words have biological traits (e.g. nasal phonetic properties in words communicating the crying of a cat) but they are not universal for every language. According to the listener, the biological traits can be different from country to country, due to different phonological systems. Obviously, people in Japan would find it strange if someone said that a cat cries 'meow'. Likewise, people in the UK would likely correct someone who says that a cat cries 'nya', by telling them that a cat actually cries 'meow'. So, the natural traits of symbolic words are prominent in the academic view but can be quite different according to the phonological system of each language in the pragmatic view. Therefore, symbolic words are not universal.

We know that the research on the arbitrariness of onomatopoeia has a significantly different result depending on if it is the speaker's mother tongue used. Let us say there are a man speaking Japanese as his mother tongue and a man speaking English as his mother tongue as well, provided that don't know any other alternative languages to find common language. If the Japanese expresses the word mune ga dokidokisuru 'pulpit' its onomatopoeia, the man notices the meaning immediately after hearing dokidoki. This is because people use a similar word that defines palpitation as onomatopoeia. However, the Japanese man might not be able to analogize after hearing the word palpitate. In Japanese, the pronunciation of pulpit is very uncom- mon. Therefore, a common pronunciation is more often used than unfamiliar pronunciation when people explain a phenomenon. Likewise, the English man who does not use Japanese as his first language might not be used to hearing the word dokidoki. For that reason, we can provide two conclusions. Firstly, onomatopoeia has no arbitrariness. As it was showed above, the reason is that people have unconscious or conscious onomatopoeia which has a similar sound to the word when they imitate some action. Some examples are as follows. In Japanese, buta 'a pig' grunts bubu. The animal name buta may originate from the grunting sound bubu. The important thing is not the order of the incident but that the object and the sound of the object have a similar meaning. It is considered to be an effort to closely combine the language and practical life. Secondly, as stated above, differences in onomatopoeia depend on the pronunciation system of each language.

Mimetic words are overlaps with onomatopoeia in a broad category. For example, daradara/taratara continuous dripping of heavy liquid like sweat, blood etc. or dragging on without end or gently sloping' can be both onomatopoeia and mimetic words in Japanese.

Let us refer to the example of da-ra-da-ra (ta-ra-tara). Its meaning is continuous dripping of heavy liquid like sweat, blood, etc. But, a question is instigated: Is the sound really like da-ra-da-ra? No, it is not. Somebody made the onomatopoeia while seeing and hearing the phenomenon and the word perhaps later became a mimetic word. It is a kind of sign or rule in society like the function of each language. Mimetic 
words are not the relation among the close word-family that can explain its meaning from the beginning. Mimetic words are admitted as a word after the word and the explanation of the mimetic words is fixed in society. Therefore, we can say mimetic words have arbitrariness.

4. Conclusion. We have shown that sound-symbolism has a role for language learning, but only in terms of learning relationships between categories of speech sounds and categories of meaning, and it does not have an influence on learning individual word meanings. Such sound-symbolism may have an effect on language learning but can only be restricted to aspects of learning where category distinctions are important but precise identification of meaning is not. It is a long established convention that the relationship between sounds and meanings of words is essentially arbitrary typically the sound of a word gives no hint of its meaning. However, there are numerous reported instances of systematic sound-meaning mappings in language, and this systematicity has been claimed to be important for early language development. In a large-scale corpus analysis of English, we show that sound-meaning mappings are more systematic than would be expected by chance. Furthermore, this systematicity is more pronounced for words involved in the early stages of language acquisition and reduces in later vocabulary development. Previous studies on language learning have shown that systematicity in sound meaning correspondences is indeed an impediment for learning individual words. For this reason, sound-symbolism is likely to be non-pervasive in natural language, and, when it does occur, is likely to be restricted to situations where it is sufficient to convey a general meaning rather than a specific identification. Whether there is an early benefit in language acquisition from exposure to these special cases of sound-symbolism, or whether the origins of language satisfied these conditions, remain open and unanswerable questions, respectively.

\title{
REFERENCES
}

Abelin, A. (1999). Studies in sound symbolism. Ph.D. dissertation, Göteborg University. (2012). Relative frequency and semantic relations as organizing principles for the psychological reality of phonaesthemes. Selected Articles from UK-CLS Meetings, 1, pp.128-145.

Akita, K. (2009). A grammar of sound-symbolic words in Japanese: Theoretical approaches to iconic and lexical properties of mimetics. Ph. D. dissertation, Kobe University, Imai, M., Saji, N., Kantartzis, K., \& Kita, S. (2013). Mimetic vowel harmony. Japanese/ Korean Linguistics, 20, pp. 115-129.

Feist, J. (2013), "Sound symbolism" in English. Journal of Pragmatics, 45(1), 2013, pp. 104-118.

Firth, J. (1930), Speech. London: Ernest Benn, London: Oxford University Press, 1964

Hamano, S. (1998), The Sound-Symbolic System of Japanese. Stanford, 1998, 262 p.

Hockett, C. F. (1960). The origin of speech. Scientific American, 203, 89-96.

Imai, M., Kita, S., Nagumo, M., \& Okada, H. (2008). Sound symbolism facilitates early verb learning. Cognition, 109(1), pp. 54-65.

Itô, J., \& Mester, A. (1996). Japanese Phonology. In J. Goldsmith (Ed.), The Handbook of Phonological Theory (pp. 817-838).

Massachusetts: Blackwell Publishers. (1999). The Phonological Lexicon. In N. Tsujimura (Ed.), The Handbook of Japanese Linguistics (pp. 62-100). Malden, MA/Oxford: Blackwell Publishers.

Kakehi, Hisao; Tamori, Ikuhiro; Schourup, Lawrence Clifford. (1996). Dictionary of iconic expressions in Japanese, Berlin: Mouton de Gruyter.

Kita, S. (1997). Two-dimensional semantic analysis of Japanese mimetics. Linguistics, 35, pp. 379-415

Monaghan, P., Mattock, K., \& Walker, P. (2012). The role of sound symbolism in language learning. Journal of Experimental Psychology: Learning, Memory, and Cognition, 38(5), pp. 1152-1164.

Shinohara, K., \& Kawahara, S. (2010). A cross-linguistic study of sound symbolism: The images of size. In Proceedings of the 36th Annual Meeting of the Berkeley Linguistics Society, Berkeley, CA, 6-7 February 2010. Berkeley, CA: UC Berkeley.

Wescott, R. W. (1980). Sound and sense: Linguistic essays on phonosemic subjects. Lake Bluff, IL : Jupiter Press.

\begin{abstract}
Анотація
У статті визначено, що форма слова успадковує довільне відношення до його змісту тільки частково для чітко окреслених відносин між формою та значенням. У процесі дослідження була розглянула роль іконічності в мові, а також існування та роль недовільних властивостей та їхнє використання. Нещодавні дослідження, написані англійською та японською мовами пропонують більш структуровану класифікацію лексики, де довільність доповнюється іконічністю (аспекти форми перетинаються з аспекти змісту слів) та систематичність (статистичні закономірності в формі передбачуваної функції). Звукосимволізми - це систематичний, недовільний зв'язок між словом та змістом. Хоча ряд біхевіористичних досліджень показує, що діти, так само, як і дорослі, дуже чутливі до сприйняття звукосимволізмів, звуконаслідувань, нейронні механізми, що лежать в основі цього явища, ще не були широко досліджені. Експериментальні дані свідчать про те, що ця форма відповідає певним значенням, які виконують різні функції при обробці мови, розробці та комунікації. Системність вивчення класів об'єктів за допомогою фонологічних сигналів та іконічністі полегшує вивчення слів і спілкування за допомогою перцептивно-моторних аналогій, а довільність - індивідуальне сприйняття за допомогою визначених форм. Існує ряд зовнішніх причини, чому конкретна форма вживається з певним значенням, однією з яких є звукосимволізми. Також є поняття систематичності використання в англійській та японській мовах, де існує більше вірогідності слів із подібними формами, ніж зі схожими значеннями. У статті використано порівняльний метод, 3 метою визначити та проаналізувати причини виникнення евфонії, а саме ментального сприйняття лексичних одиниць, а також для виміру частотності вживання таких одиниць, вплив звукосимволізмів та звуконаслідувань на цей процес використано порівняльний метод.
\end{abstract}

Ключові слова

Звукосимволізми, звуконаслідування, довільність, ономатопеї, ідіофони, іконічність. 


\section{OUR AUTHORS}

Olha Vasilyeva, Grammar Department of Odessa I. I. Mechnikov National University; lecturer at Languages Department of National University "Odessa Law Academy"; 2 Akademichna str., Odessa, 65009, Ukraine; e-mail: vasylyeva@inbox.ru

Snizhana Holyk, Associate prof., Cand. of Sc. in Philology, State University "Uzhhorod National University", Universytetska Str., 14, 88000, Uzhhorod, Ukraine; e-mail: snizhana.holyk@uzhnu.edu.ua

Darya Kaysina, Lecturer at Mykola Lukash Translation Studies Department, School of Foreign Languages at V. N. Karazin Kharkiv National University, 4 Svobody Sq., Kharkiv, 61022, Ukraine; e-mail: darya.kaysina@karazin.ua

Olena Kashchy, department of Foreign Languages № 2, National University "Odessa Law Akademie"; 23 Fontanskaya Doroga, 65009, Ukraine; e-mail: elena.kashchy@gmail.com

Oksana Kodubovska, Zhytomyr Ivan Franko State University, 40 Velyka Berdychivska str., 10008-Zhytomyr, Ukraine; e-mail: kodubovskaya@gmail.com

Ekaterina Lesnevskaya, Senior Lecturer, National University Odessa Law Academy, 23 Fontanskaya Doroga, 65009, Odessa, Ukraine; e-mail:katlev@ukr.net

Natalia Petlyuchenko, Prof. Dr., Head of Foreign Language Department № 2, National University “'Odessa

Law Academy"; 23 Fontanskaya Doroga, Odessa, 65009, Ukraine; e-mail: natalja.petljutschenko@onua.edu.ua

Serhii Potapenko, Prof. Dr., Gogol State University at Nizhyn, Grafska Str., 2, 16002, Nizhyn, Ukraine; e-mail: serhiy.potapenko@ndu.edu.ua

Liudmyla Pradivlianna, Assistant Prof., Cand. of Philol. Sc., National Pedagogical Dragomanov University; vul. Turgenivs'ka, 8/14, Kyiv, Ukraine; e-mail: lyu2005pra@gmail.com

Dariia Rzhevska, Lecturer, Academic and Research Institute of International Relations, National Aviation University, prosp. Kosmonavta Komarova 1, Kyiv, 03058, Ukraine; e-mail: by_odry@ua.fm

Larysa Chayka, PhD, Associate Professor, Research and Educational Center of Foreign Languages, National Academy of Sciences of Ukraine; Triokhsviatytelska St., 4, Kyiv, 01601, Ukraine; e-mail: ChaykaLV@nas.gov.ua

Ludmila Shapa, Assoc. Prof. PhD, Odessa National Polytechnic University, Tenistaya, 7, 16, 65009-Odessa, Ukraine; e-mail: shapa.od@gmail.com

Maria Nevreva, Assoc. Prof. PhD, Odessa National Polytechnic University, Shevchenko av., 10/7, 21, Odessa-58, Ukrain; e-mail: m.n.nevreva@gmail.com

Marina Tsinovaya, Assoc. Prof. PhD, Odessa National Polytechnic University, Profsoyuznaya, 10b, 65076Ю-Odessa, Ukraine; e-mail: marinatsinovaya@gmail.com

Olga Iakovlieva, Prof. Dr., Odesa National I.I. Mechnikov University, Dvoryanskaya Str., 2, 65082, Odesa, Ukraine; e-mail: olga.yakovleva.1920@gmail.com

Viktoriia Hryhorash, PhD, Odesa National I.I. Mechnikov University, Dvoryanskaya Str., 2, 65082, Odesa, Ukraine; e-mail: viktoriiagrygorash@gmail.com 